\title{
Ductal Breast Hyperplasia
}

National Cancer Institute

\section{Source}

National Cancer Institute. Ductal Breast Hyperplasia. NCI Thesaurus. Code C9492.

Hyperplasia of the epithelial cells in the breast ducts. It includes the atypical ductal

hyperplasia, papillary intraductal hyperplasia, intraductal myoepitheliosis, and ductal hyperplasia of the usual type. 